\title{
Small and Medium Enterprise: Clear Pathway to Bright Future By Using Fundamental Visionary Life Cycle and Difficulties Overcome Diagram
}

\author{
S.M.Emdad Hossain
}

\begin{abstract}
Fundamental visionary life cycle (FVLC) is almost prerequisite of difficulties overcome diagram in business (DODB). FVLC is to keep encouraging people to go for business. Before going for business, FVLC will work like awareness program. On the other hand, DODB is to solve the problem in business. Whatever the problem is, it is possible to track and solve by using the DODB. DODB will work like an equation "Problem equals to solution". It means once problem occurred in business, immediately the solution will stay beside. Hence, the research on small and medium enterprise (SME) on regards to fundamental visionary life cycle and difficulties overcome diagram is to build up solid-business-intelligence for SME industry.
\end{abstract}

Index Terms-Business-intelligence, developing economy, DODB, FVLC

\section{INTRODUCTION}

Small and medium enterprise is very common and effective business piece of modern economy. Micro, small and medium-sized enterprises (SMEs) are the engine of the European economy. They are an essential source of jobs, create entrepreneurial spirit and innovation in the EU and are thus crucial for fostering competitiveness and employment [1]. We found that the effectiveness of small \& medium enterprise is more on developing economy. A vibrant SMEs sector can play a key role in creating jobs and high economic growth. It has the most potential to provide employment for the $70 \%$ of the labour force still working in agriculture (India). Achieving and sustaining such growth and higher employment will require a boost in industrial and services growth, spurred by SMEs [2]. The importance of small and medium-sized businesses in helping the economic development of our nation cannot be refuted. Besides creating job opportunities, SMEs play a crucial role in contributing to the prosperity of big and multinational corporations. They enhance the industry through their creativity and innovation [3]. By understanding the importance, a possible approach can make easier for every single deserving people to get-in by utilizing of Fundamental Visionary Life Cycle (FVLC) and Difficulties Overcome Diagram in Business (DODB) "Problem equal to Solution". The main aim of this research is to provide a clear direction for small and medium enterprise to grow up with success and benefit in conjunction of fundamental visionary life cycle

Manuscript received July 25, 2011; revised September 21, 2011.

S.M.Emdad Hossain is with the Faculty of Information Science \& Engineering, University of Canberra, Australia.Tel: +61-02-62012329

Fax: +61-0262015231, (Email: emdad.hossain@canberra.edu.au)
(FVLC) and difficulties overcome diagram. My invented both diagram is clear and most potential approach for our young people, potential entrepreneur, unemployed people and the people those who are struggling with their business. The mentioned approach would work as inspiring engine for small and young business.

\section{BACKGROUND}

Small and Medium Enterprises are key factors for developing economies since it is best practice for economic growth. We can find prove contribution from SMEs to developed and industrial country. The contribution of SMEs to the Malaysian economy is relatively low (31\% to GDP) when compared with the industrial countries and other developing countries, which range between $40 \%$ and $60 \%$ of GDP [4]. The quote shows Malaysian SME has around 30\% contribution to their economy. In fact, some the Asian countries like Bangladesh; Nepal has SME contribution not even $20 \%$ to GDP. Research shows, modern and thriving SME sector supports the transformation of the economy by creating jobs and helping the innovation and adaptation of the economic system [5]. Most SMEs meet grave obstacles due to: the nature of transition, including the lack of relevant institutions, and infrastructure, the experience and the expertise necessary to successfully operate in a competitive market economy. Poverty and low income suppresses demand for SMEs and prevents the formation of investment capital; and results in policy mistakes, including the inconsistency and instability of policies and their SME-averse character. With disruption of government and the spread of criminality, these factors have caused uncertainty and insecurity for SMEs and gave an indirect boost to tax evasion and regulation avoidance as adaptation mechanisms [5]. Hence, it is becoming very much tough to run through the business. As a result some of them cutting down or shutting down the business. Unfortunately it will effect on national economy at sharp point. Some enterprises don't know how to apply the business policy, what are the exact points to recover from any damage or lost. Malaysian SME Corporation has also been tasked to undertake the SME Master plan (2011-2020) to chart the policy direction of SMEs and aligning to the New Economy Model. The draft plan which comprises the overall policies and strategies is scheduled to be completed in the first quarter [4]. It means Malaysian government found that the finest, faster \& smarter way to develop the economy; which is to develop on SME sector. I think we can have a look on the SME contribution percentage to GDP of developed nation. It shows the contribution rate is around $40 \%-60 \%$. Here we should take 
note, if a developed economy depends on at least $50 \%$ of their SME industry, no need to justify the necessity of development of SMEs in developing countries. In addition, some country like India has significant development on SMEs e.g.; the magnitude of contributions as well as the impact of small scale industry (SSI) on the economic growth and development of India is highly significant as evidenced by the following figures. The SSIs represent ninety-five percent $(95 \%)$ of the total industrial units in India, contribute forty-five percent $(45 \%)$ of the total industrial output, account for eighty percent $(80 \%)$ of all employment in the industrial sector, and contribute thirty-five percent $(35 \%)$ each of total exports and value added by the entire manufacturing sector respectively in India. Between 1990 and 1991, SSI real growth in India recorded between a low of $7.1 \%$ in $1993 / 94$ and a high of $11.3 \%$ in $1996 / 97$ [6]. The necessity of smart growth of SME industry is now deployed by all most every nation. Developing to developed nations, they realized that development of SME is fastest and smart way to boast-up of the economy. Very recently, the Queensland government of Australia has been declared particular scheme for SME sector [7]. Not only in Australia, is SME now boasting up around the world and that becoming one of main element of modern economic development. Likewise, researchers found the American economy mostly driven by small business, report said, "Small business drives the American economy," said Dr. Chad Moutray, Chief Economist for the Office of Advocacy in a press release. "Main Street provides the jobs and spurs our economic growth. American entrepreneurs are creative and productive, and these numbers prove it." Small businesses are job creators. Office of Advocacy funded data and research shows that small businesses represent 99.7 percent of all firms, they create more than half of the private non-farm gross domestic product, and they create 60 to 80 percent of the net new jobs. In 2004, there were an estimated 23,974,500 businesses in the U.S. Of the 5,683,700 firms with employees, 5,666,600 were small firms [8]. It is now clear that most of the developed nation or developed economy based on SME. If we look on Japanese economy, how much depend on their SEM's; 99.2\% of all businesses are SMEs (5.7million entities). SMEs have provided a safety net by covering $70-80 \%$ of total employment. $60 \%$ of SMEs have direct or indirect transactions with large enterprises in the manufacturing industry [9]. We mostly discussed Asian economy, American economy and European economy in terms of SME. Let us go through on SME in Africa. Africa's private sector consists of mostly informal microenterprises, operating alongside large firms. Most companies are small because the private sector is new and because of legal and financial obstacles to capital accumulation. Between these large and small firms, SMEs are very scarce and constitute a "missing middle." Even in South Africa, with its robust private sector, micro and very small enterprises provided more than 55 per cent of all jobs and 22 per cent of GDP in 2003, while big firms accounted for 64 per cent of GDP. SMEs are weak in Africa because of small local markets, undeveloped regional integration and very difficult business conditions, which include cumbersome official procedures, poor infrastructure, dubious legal systems, inadequate financial systems and unattractive tax regimes. Many firms stay small and informal and use simple technology that does not require great use of national infrastructure. Their smallness also protects them from legal proceedings (since they have few assets to seize on bankruptcy) so they can be more flexible in uncertain business conditions [10]. However there is doubt if African SMEs can take advantage of the potential opportunities globalisation affords and successfully compete in such a global environment, given the numerous problems they are beset with. In many African countries, SMEs operate under an unfriendly policy and regulatory environment, have difficulties in accessing credit, lack sufficient markets for their products, use outdated technology, lack adequate working place and have no sufficient training facilities that design their programmes in response to their specific needs etc. If these SMEs are to play any meaningful role in regional and global markets, they have to be put on a footing similar to their competitors. Yet to put them on such a footing requires nurturing them and providing support in strategic areas [11].

Moreover, the prospectus and resourceful SME can have long drive to our national economy; no more prove require by putting the truth in front. However, on the way to development, SME facing number of problem in terms of investor, administrator, government low, policy making, management and so on. I personally believe, it is easy to win, if you know how. SME sector facing problem and economic growth will fall down, no one want that. Here in this paper, I tried to describe on a package which can be considered as inspiration tools. My paper would be kind of tonic to develop SME some countries in Asia and Africa within their huge limitation. It is also workable to developed economy like country in Europe, America and Australia. In Next section I will discuss on the mentioned tools.

\section{SME SOLUTION}

Research shows that, the skills and experiences of an entrepreneur are not necessarily sufficient to grow the business to a much larger size. Further stages in the company's development require, amongst other things, new technologies and the know-how to implement them, new staff, with additional skills, and access to new markets. And of course, financial investment is a major requirement for growing a firm, as is often face-to-face advice and support and help in accessing new markets [12]. Even though the mentioned research focused on large scale business, still this is true for SME as well. This is obvious that most of the SMEs going to shut down only because of skills of experiences of respected entrepreneur. Furthermore, in business, success depends on existing environment. All over the world, not all the environments are suitable for different kinds of business. So we have to find our suitable environment to operate our business. Besides, we may not find suitable environment which we will look for but still we have to do our business and we have to go ahead with our business. Here is role for skills and experiences. In this case, we should create our own business environment which will be more effective and efficient. You can talk with well established business-man, your field related business-man within your region. You can share your idea; you can make friendship as well. The friendships are not for your personal interests but it's just to make a good business environment. 
Well, you may have someone who is holding large business and having big position but you are small in comparison to them. In that case, you can think, you are a business man and they are also business man. There is nothing unequal. You also can think, you are staying in an equal platform with them Even though, you are new, try to be smart, be business minded, be punctual and be confident. Finally you will get an excellent business environment which will accelerate your business performance to a positive direction. Furthermore, you should consider the environmental issue seriously. If you live with an economist, definitely you will learn something about economics and that will come to you involuntarily. For example, if you live with a singer, you may get interested in singing. So, you need to live with a particular business environment which can promote you to a well-built business platform. This is not to say that you have to forget about everything except your business but you have to be sincere to business specially in business hours.

\section{Definition Of Business}

The word business means commerce or trade. Producing or selling something is called business. Business is kind of job that we do, to lead our life in a happy and successive way. And in large prospect, business is a higher level economic device. However, there are several definitions of what constitutes of small and medium business. A small business is sometimes viewed as an enterprise engaged in trading activities or a retail store selling consumer goods. At other times, it is defined as a business entity that is neither owned by the public nor listed on the stock exchange. It is common to define the size of a business based on the annual turnover or sales generated, number of workers employed, paid-up capital or market sized served. The definition differs from one country to another to reflect, among others, the economic and the political interests of the nation [3]. However, People are doing various kinds of business in their life. Someone is succeed and someone is not. Whenever you judge the business is to lead your life, then the word failure has to keep out of your life dictionary.

\section{Business Mind SET-UP}

Earlier I have mentioned, business is the soul of economy. The word economy exists whole of our life in terms of personal, society, national and world economy. Attention is most important element of any kind of task. You have to be more attentive to do your own job. Same goes to business sector. You have to take care of your business. Continually you have to keep your eyes on your business. More often you should appraise your business condition. Finally, to get attention into your business, you should think "this is the way I can board in to get financial success of my life". Besides, you have to be constant to hunt your business success and no choice to come back without success. You need to keep in mind, now a day's money works as life explorer. Without money you can't explore at all and it's becoming true. If you don't have money, no one likes to talk with you. Moreover, if you don't have enough money, even your most nearer people may tell you rubbish. So, no way!! Be business minded and get success with your business as soon as possible. If your previous living environment is not suitable for a business man, you should stay far from that environment at least for few months. Within this few months you can settle yourself. Accordingly, get start your business and make yourself as a member of successful business-man club.

\section{RIGHT BUSINESS}

In the world the numbers of existing businesses are many, and can't be counted on fingertips. With regards to products and services there are huge numbers of business sector are on operation right now. It's proud to say that, day by day the number of businesses is increasing at very fast pace and generating more new ideas. All of solitary ideas are creating new strategy in business era. As a result, business firms are getting more competitors and consumers getting more substitutes. People are getting new business ideas, having new business fields, making wide commercial highways. Hence, business world becoming much extensive and rich [13]. Exact thing is, if you want you will have a business and there is no doubt at all. Now, it's your turn to find out your business according to your ability and interest. In addition, every person has some unique identity or unique characteristics. Most of your interest will come from your uniqueness and environment. First of all, you need to think, who I am, what my background is, what I did previously, and now what I can do with my previous experience. Subsequently, you will get your expected business. Whatever business is your choice, make sure it's within your field of interest, otherwise that might be tough for you to sustain. The business you have chosen, it may be small but you have to be full of motivation to make it bigger. You can remember, most of the large business organizations came from a small dais.

\section{IMPLEMENTATION OF FUNDAMENTAL VISIONARY LIFE CYCLE}

To drive in highway, you have to know the road as well as rules and regulations. To be a successful business man, you should follow some essentials criteria. First of all the owner should select the right business in a right place. Here, we should take care for three major things that are: 1) Vision 2) Mission and 3) Success. Everybody should have fastidious life vision, and then, that particular vision will promote to a mission. To make success on your vision, you need to have exact mission. The constructive mission will bring you to your expected success or expected point. We can have more clear idea from the fundamental successive business life cycle below:

However, men cannot do anything without proper plan. You have to have visionary business plan to lead our life expect fully. While you're holding your plan in mind, then you have to think how I can make it possible. I suggest, you should find out at least TEN paths to make that successful. After getting ten possible ways, you have to segment the entire path according to effectiveness. Finally you can apply one after another. In this stage, I'm enough confident that, if you can apply to the point and if you can walk to the right way, you will be succeed in your business. You should keep in mind; time will not wait for you. In fact, you have to wait 
for the time and then your time will come to you.

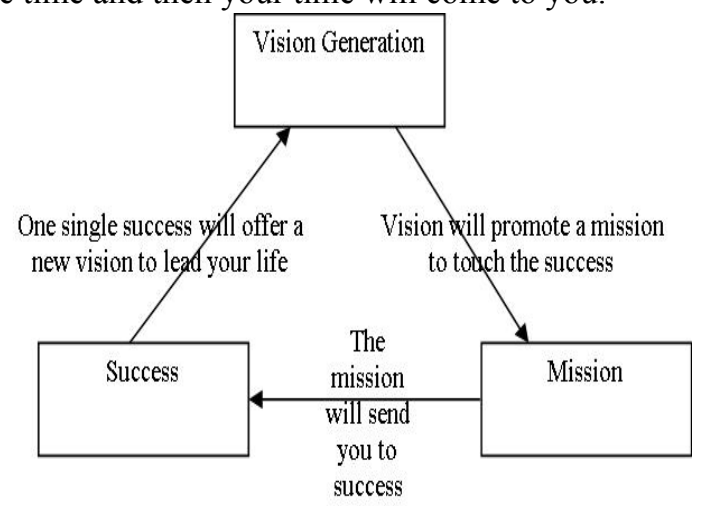

Fig.1.Fundamental Visionary Life Cycle

\section{IMPLEMENTATION OF DIFFICULTIES OVERCOME DiAGRAM (PROBLEM EQUAL TO SOLUTION)}

The word critical path means the way having some restriction to go but still it's legal if you can manage. Business may have and may come-up with some problem; we can consider that as critical path within the flow of a business. You should take any problem easily and its universal truth that, competitiveness, difficulty, criticality are parts of business. You have to think this is normal and of course you are able to overcome. This is kind of physiological teach. The scenario is, you will be very much weak, if you think someone smarter than you or your competitors are smarter than you. However, you have to think you are good enough to deal with the problem which is going on and of course your opponent (the problem) not smarter than you. Be confident and go ahead smartly and formally, and for sure, success will come to you. If you get any problem on your business, just try to analyse the problem and find out the reason. Hence, you can consider all the detected reason as your weakness and instantly make effort to recover the weakness. Find out a set of solution to overcome and apply one after another. Finally you will see the expected success at your hand. Here, my logic is "Anyone can do business, as long as he/she has intension to make it possible and there is no such restriction which is not beatable". Nevertheless, you can get more clear idea to solve any business problem by utilizing the following diagram. Let's have a look the Difficulties Overcome Diagram in Business:

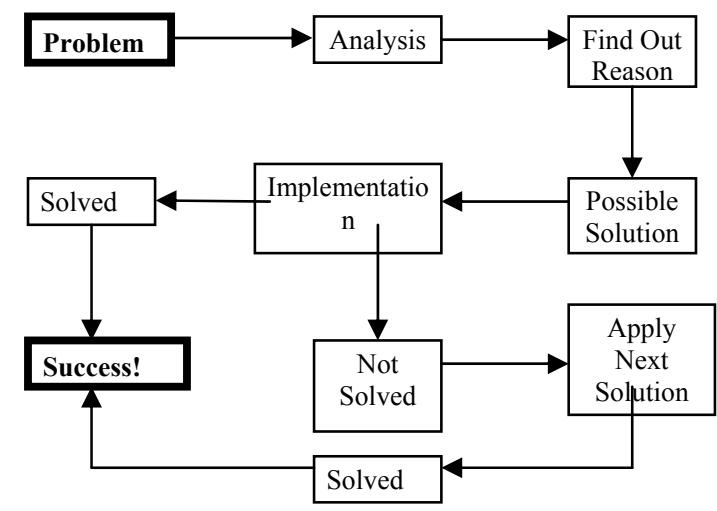

Fig.2. Difficulties Overcome Diagram in Business Moreover, the drawn diagram conveys an absolute determination message to the SMEs personal. That's providing inspiration to build up self confidence to run with business at any condition. Business might have upward and downward trend but still we have to make that equal to run with. Give up must be out of business phenomenon. That is one of main lesson of the DODB. DODB will work like introduction to business development, business enhancement, part of strength \& weakness analysis and put on right solution. Once we analyse each and every step of a problem, for sure we will receive particular feedback on strength and weakness of our business.

\section{HONEST In Business}

Honesty is the permanent entity of human dignity. Wherever you go and whatever you do, you have to be honest. Your honesty should be your main approach to go ahead with your business. People may ask how much successful you are, but before that they will search how much honest you are. However, honesty is the only way to be a successful business-man in-consists of real meanings of "success". You may gain something by dishonesty but the longevity of that success is very poor and there is no argument. The success you gain with honesty that is pure and longer stable. Let's have a look at few tips to be an honest business man.

- Never provide wrong information to your customer or client

- Never break commitment which you already made with your client.

- Never steal idea from anyone but try to generate new idea.

- Never apply other's successful idea without giving enough references.

- Don't forget the time of the basement of your business and always respect to that time, environments and related people.

- Always care your business quality.

- Profit, customer service and quality of goods must have same preference.

- Always promote legal strategic plan.

- Try to combine honesty with professionalism.

- Monitor your task everyday in terms of time, quality and purity.

- Finally monitor your employee's honesty.

Conversely, you are maintaining all of the above tools, now imagine what you can do and how far your business will go. I strongly suggest maintaining all the mentioned tools, and then see what the output is. Yes, you will receive your expected business milestone within short period of time, no matter how small you are.

\section{Conclusions}

Finally, I can recap that I wrote the paper in a directive way just to make direct influence to targeted people. I tried to focus especially to young entrepreneur, degree level student those who are knocking their processional life, those who are struggling with their business and those who are having small amount of capital. I hope and expect by exploring the piece of 
writing all the above mentioned people will be benefited and I'm confident. It will be a special indicator for unemployed young society and it will work as an accelerator for them to build their life in a new, positive and successive manner. It will help them to build up a business and to get financial freedom. At the end it is highly recommended to upcoming entrepreneur and SME owner to have self confidence. In fact, a good confidence is to be constant under any circumstances. So, try to be constant with your decision which you already made legally. We always have to keep in mind, If you like to do something for your society, you have to be established first, and then you can work for the society, for the people and for the nation, but the personal establishment must be in legal way. And the easiest legal way is legal business. And easiest entrance to business is; start with small and smart business.

\section{REFERENCES}

[1] The new SME definition, User guide and model declaration, Enterprise \& Industry Publications, European, Commission, Günter Verheugen, January 2005,

[2] Small and Medium Enterprises: India's Engines of Growth, March 9, 2010,

[3] Radient In: BizTalk, Background, Definition and Characteristics of SME in Malaysia, 17 Oct, 2008

[4] D. Daljit, Raising the bar, Saturday January 15, 2011, www.thestar.com.my

[5] D.D. Un, The importance of small and medium enterprises - Transitional Economies, Chronicle, December2003, http://findarticles.com/p/articles/mi_m1309/is_4_40/ai_114007081/

[6] B.A.N. Onugu (FIMC, FICA), Small \& Medium Enterprise (SMEs) in Nigeria: Problem \& Prospects, 2005, ST. CLEMENTS UNIVERSITY

[7] SME Participation Scheme, department of employment, economic development and Innovation, the Queensland government, Australia http://ict.industry.qld.gov.au/industry- support/244.htm

[8] Robert Longley, Small Business Drives U.S. Economy, About.com, US government info.

[9] N. YOKOSHIMA, Support program for SME IP activity in Japan, WIPO forum on intellectual property and small and medium-sized enterprises 13 September 2007

[10] C. Kauffmann, Financing SMEs in Africa, Policy Insights No.7 is derived from the African Economic Outlook 2004/2005, a joint publication of the African Development Bank and the OECD Development Centre, www.oecd.org/dev/aeo

[11] Economic Commission for Africa, Report of the Workshop on the theme .Enhancing the Competitiveness of Africa SMEs in Regional and Global trade: The Role of Support Services, Organised by ECA in collaboration with Small and Medium Industries Development Organisation of Mauritius, Radisson Beach Hotel, 27 November to 1 December 2000.

[12] Small and medium-sized enterprises (SMEs), Improving the business environment: starting, running and growing a business, Europian Comission, Enterprise and Industry

[13] S.M.E.Hossain, Development of Fundamental Visionary Life Cycle and Difficulties Overcome Diagram for Small and Smart Business, International Conference on Sociality and Economics ICSEP, 17-19 ${ }^{\text {th }}$ June, Kuala Lumpur 2011

[14] A.U. Kari, Small \& Medium Business Enterprise and the use \& adoption of Information \& Communication Technology, A Study of legal Issues and Legal Perspectives, International Journal of Organisational Behaviour, Volume 12 (1), 144-160.

[15] Madden, K, Scaife, W and Crissman, K, 2006, How and Why Small to Medium Size Enterprises (SMEs) Engage with their Communities: an Australian Study. International Journal of Nonprofits and Voluntary Sector Marketing 11(1):pp. 49-60. Copyright 2006 John Wiley \& Sons

[16] A.Mohsena, M.Abdulla, A.Jalal, How Financial Organizations Can Overcome the Global Business Crisis, International Journal of Business and Management, Vol. 6, No. 2; February 2011.

[17] CSIRO's Small and Medium Enterprise Engagement Centre, http://www.csiro.au/solutions/SMEEngagement.html

[18] Government to give small firms more state contracts, Fri Feb 11, 2011,http:/uk.reuters.com/article/2011/02/11/uk-britainbusinesses-small-idUKTRE71A43T20110211

[19] Dr. J. Pope, H. A. Jabbar, Tax Compliance Costs of Small and Medium Enterprises in Malaysia: Policy Implications, June 2008, Curtin University of Technology

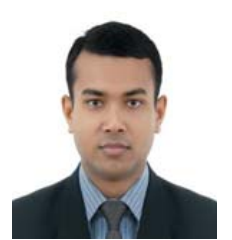

S.M.Emdad Hossain is a Post Graduate (Research) student in Faculty of Information Science and Engineering in University of Canberra. He also started his teaching in the same faculty. Prior to come to University of Canberra, he was doing Master of Information System in Central Queensland University, Australia. He also received Bachelor in Information Technology (Hons) from Multimedia University, Malaysia. He published number paper in International Conference and Journal. His research interests include biometric technology, computer security and pattern recognition. However, business development and advance marketing are in his area of special interest. 